\title{
Application of Electrochemical Technology for Water Treatment of Brazilian Industry Effluents
}

\section{Camila Carvalho de Almeida, Patricia Rachel Fernandes da Costa, Maria Jucilene de Macedo Melo,} Elisama Vieira dos Santos, and Carlos A. Martínez-Huitle*

Federal University of Rio Grande do Norte, Institute of Chemistry, Lagoa Nova - CEP 59.072-970, RN, Brazil. Phone/Fax: +55 (84) 3211-9224. carlosmh@quimica.ufrn.br

Received February $7^{\text {th }}, 2014$; Accepted March 11 th 2014.

\begin{abstract}
Electrochemical technologies are a promising alternative for the treatment of wastewaters containing organic pollutants. The main advantages of these processes include environmental compatibility, versatility, energy efficiency, safety, selectivity, amenability to automation and cost effectiveness. However, the effectiveness of the electrochemical approaches depends strongly on electrode materials and cell parameters (mass transport, current density, water composition, etc.). Then, the use of high performance anodic materials can achieve high efficiency and lower the operating cost. Therefore, several research groups are recently studying the applicability of the electrochemical technologies for treating real domestic and industrial effluents, with the aim of that a diversification of techniques must be sought, adapting the treatment to each situation, as much as possible. In this context, this paper presents an overview of the application of electrochemical technologies to treat industrial effluents in the northeastern region of Brazil, emphasizing the use of direct and indirect electrochemical oxidation processes as an alternative to pollution abatement of effluents generated by textile and petrochemical industries.
\end{abstract}

Keywords: electrochemical technologies, real effluents, Brazilian industries.

\section{Introduction}

\section{Brazilian Northeastern industries}

Recently, Brazil is one of the most important emerging-economic countries, and it is due to its advance on several socialpolitic-economic aspects [1]. The Brazilian fastest-growing economy has been due to the strong scientific, technological and industrial development in the last years. Brazil's diverse industries range from automobiles, steel and petrochemicals to computers, aircraft, and consumers durables. With increased economic stability provided by industry progress, other problems have been appeared, such as environmental [2].

In the case of Northeastern region, the petrochemical and textile industries are the most important economic sources. However, some of them are at expense of the environment, including the aquatic environments. With this in mind, the effective treatment of effluents represents a serious problem, especially for the chemical industry. Over the last twenty-five years, huge efforts have been made to limit at the source this type of pollution, by improving processes, recycling products
Resumen. Las tecnologías electroquímicas son una alternativa prometedora para el tratamiento de las aguas residuales que contienen contaminantes orgánicos. Las principales ventajas de estos procesos incluyen la compatibilidad ambiental, versatilidad, eficiencia energética, seguridad, selectividad, susceptibilidad a la automatización y un costo efectivo. Sin embargo, la eficacia de los procesos electroquímicos depende fuertemente de los materiales de los electrodos y los parámetros del reactor electroquímico (transporte de masa, densidad de corriente, la composición del agua, etc.) Entonces, el uso de materiales de alto rendimiento anódico favorece una alta eficiencia y reduce el costo de operación. Por lo tanto, varios grupos de investigación están estudiando la aplicabilidad de las tecnologías electroquímicas para el tratamiento de efluentes domésticos e industriales reales, con el objetivo de que buscar la diversificación de las técnicas, adaptando el tratamiento a cada situación, tanto como sea posible. En este contexto, el presente trabajo de revisión presenta una visión general de la aplicación de las tecnologías electroquímicas para el tratamiento de efluentes industriales en la región noreste de Brasil, haciendo hincapié en el uso de procesos de oxidación electroquímica directa e indirecta, como alternativa a la reducción de la contaminación de los efluentes generados por las industrias textiles y petroquímicas.

Palabras clave: Tecnologías electroquímicas, efluentes reales, Industrias brasileiras.

and controlling the treatment of wastes at the production stage. However, considering the large amounts of industrial effluents to be treated, for example to retrieve certain solvents, there are inevitably residues requiring a final transformation, which is often delicate.

\section{Petrochemical industry}

The significance of oil and natural gas in modern civilization is well known. The process of refining crude oil consumes large amounts of water. Consequently, significant volumes of wastewater are generated. Oilfield wastewater or "produced water $(\mathrm{PW})$ " contains various organic and inorganic components that can pollute surface and underground water and soil [3].

The volume of petroleum refinery effluents generated during processing is $0.4-1.6$ times the amount of the crude oil processed [4]. Thus, based on the current yield of 84 million barrels per day (mbpd) of crude oil, a total of $33.6 \mathrm{mbpd}$ of effluent is generated globally [5]. World oil demand is expected to rise to 107 mbpd over the next two decades, and oil will account for $32 \%$ of the world's energy supply by 2030 , while biofuels (in- 
cluding ethanol and biodiesel) are expected to account for 5.9 mbpd by 2030, and the contributions from renewable energy sources like wind and solar power are estimated to be $4-15 \%$ [5-7]. These data clearly indicate that effluents from the oil \& gas industry will continually be produced and discharged into the world's main water bodies.

As regards the significant matter of environmental concern, many countries have implemented more stringent regulatory standards for discharging PW. On the other hand, because large volumes of PW are being generated, many countries with oilfields, which are also generally water-stressed countries, are increasingly focusing on efforts to find efficient and cost-effective treatment methods to remove pollutants as a way to supplement their limited fresh water resources.

\subsection{Produced water}

Naturally occurring stones in subsurface formations are generally permeated by different underground fluids such as oil, gas, and saline water. Before trapping hydrocarbon compounds in rocks, they were saturated with saline water. Hydrocarbons with lower density migrated to trap locations and displaced some of the saline water from the formation. Finally, reservoir rocks absorbed saline water and hydrocarbons (oil and gas). There are three sources of saline water: (i) flow from above or below the hydrocarbon zone, (ii) flow from within the hydrocarbon zone and (iii) flow from injected fluids and additives resulting from production activities [3].

The last category is called "connote water" or "formation water" and becomes "PW" when saline water mixed with hydrocarbons comes to the surface $[3,8]$. In oil and gas production activities, additional water is injected into the reservoir to sustain the pressure and achieve greater recovery levels. Both formation water and injected water are produced along with hydrocarbon mixture. At the surface, processes are used to separate hydrocarbons from the produced fluid or PW [9]. Then, PW is considered to be one of the largest waste streams in the petroleum, oil and gas industry. Effects of PW components on the environment are [1]: (i) increase in the salinity, (ii) dispersed and soluble oil contribution in marine ecosystems, (iii) inclusion of other compounds from treating chemicals, (iv) higher concentration of heavy metals than in seawater and (v) presence of radionuclides.

PW characteristics depend on the nature of the producing/storage formation from which they are withdrawn, the operational conditions, and chemicals used in process facilities. The composition of PWs from different sources can vary by order of magnitude. However, PW composition is qualitatively similar to oil and/or gas production [10]. The major compounds of PW include: (i) Dissolved and dispersed oil compounds (a mixture of hydrocarbons including benzene, toluene, ethylbenzene, and xylenes (BTEX), naphthalene, phenantherene, dibenzothiophene (NPD), polyaromatic hydrocarbons (PAHs) and phenols), (ii) Dissolved formation minerals, (iii) Production chemical compounds (include some chemicals that are added to treat or prevent operational problems), treatment chemicals (production treating, gas processing, and stimulation) and production treating chemicals (scale and corrosion inhibitors, biocides, emulsion breakers, antifoam), (iv) Production solids (including solids formation, corrosion and scale products, bacteria, waxes, and as phaltenes) and (v) Dissolved gases [8]. Water cannot dissolve all hydrocarbons, so most of the oil is dispersed in water [9]; and dissolved and suspended oil present in PW (prior to treatment) depend on several factors $[3,11]$.

\subsection{Treatment of PW}

Considerable studies have been conducted to investigate new treatment technologies in order to treating PW. An extensive literature reporting the characteristics and applications of most important conventional technologies developed for this purpose including physical-chemical and chemical methods, advanced oxidation processes (AOPs), microbiological treatments and biological decomposition, has been collected in an authoritative review [3]. Fakhrul-Razi et al. have indicated that oil content and salinity of PW from offshore and onshore activities can be reduced through various physical, chemical, and biological methods [3]. In offshore extraction facilities due to space constraints, compact physical and chemical treatment technologies are preferred. However, as capital cost of physical methods and cost of chemicals for chemical treatment of hazardous sludge is high, the application of these methods is limited. Current methods cannot remove minute suspended oil and/or hazardous dissolved organic and inorganic components. In contrast, biological treatment is a cost-effective method for removing dissolved and suspended compounds from oilfield wastewater in onshore extraction facilities. Nevertheless, electrochemical technologies for destroying petrochemical pollutants from PW have showed great attention in the last years [12-19]. Therefore, a general overview of lab and pilot plant experiments related to the most relevant applications of electrochemical methods for removing petroleum hydrocarbons from PWs will be presented.

\section{Textile industry}

The exact amount of synthetic organic dyes produced in the world is unknown, although financial reports estimate their continuous increase in the worldwide market up to about $\$ 11$ billion in 2008 with a production of dyestuffs over $7 \times 10^{5}$ tons $[20,21]$. A large variety of these compounds are extensively used in many fields of up to-date technology involving various branches of the textile industry. Dyes are commonly classified from their chromophore group. The majority of these compounds consumed at industrial scale are azo $(-\mathrm{N}=\mathrm{N}-)$ derivatives, although antraquinone, indigoide, triphenylmethyl, xanthene, sulfur and phtalocyanine derivatives are frequently utilized [21].

Important quantities of synthetic dyes are discharged in the environment from industrial effluents [20-22]. A loss of $1-2 \%$ in production and $1-10 \%$ in use are a fair estimate. For reactive dyes in the textile industry, their loss can be about $4 \%$ [21]. The presence of these pollutants in waters can change their appearance, e.g. $1 \mathrm{mg} \mathrm{dm}{ }^{-3}$ of a dye is likely to cause 
visible colorization of the water or alter the clarity. Due to their large-scale production and extensive application, synthetic dyes can cause considerable non-aesthetic pollution and are serious health-risk factors.

The pollution potential of textile dyes and intermediates compounds was first raised due to its toxicity and carcinogenicity that can cause damage to human health and environment. It should be mentioned that coloration in water courses affects water transparency and gas solubility [22].

Thus, the development of treatment technologies suitable for the removal of color and reduction of toxicity of textile effluents is important. For the removal of dyes from wastewater a wide range of techniques have been developed and proposed [21]. However, the bioremediation technology is the most useful industrial treatment currently. It offers several advantages; it can be performed on site; generally has lower cost and minimum inconvenience in the process; eliminates the waste permanently and it can be used in conjunction with methods of physical and chemical treatments. It has minimal environmental impact and, therefore, has good public acceptance, with the regulatory encouragement. Nevertheless, this process has some limitations: long times and specific treatment conditions. Certain chemical compounds are not susceptible to the bioremediation, for example, heavy metals, radio nucleotides, complex molecules, biorefractary and some chlorinated compounds; the time needed to develop effective systems for the target compounds can be long [21].

On the other hand, traditional physical-chemical treatments applied to the purification of dyeing wastewaters include adsorption with inorganic (mainly, activated carbon materials) and organic supports, coagulation by lime, aluminum or iron salts, filtration and ion exchange. These procedures lead to effective decolorization, but their application is restricted by the formation of sludge to be disposed or by the need to regularly regenerate the adsorbent materials [22]. Other chemical methods such as ozonation and oxidation with hypochlorite ion, as well as advanced oxidation processes also provide fast decolorization, along with degradation of dyes. However, the use of these methods is not completely accepted at present because they are quite expensive and have operational problems [23]. For all these reasons, several scientific groups investigate the application of electrochemical alternatives for removing dyes from effluents [20, 24-27]. In this context, this review also summarizes the results of a selection of papers dealing with electrochemical oxidation [27-31], which is proposed as an alternative for treating real textile effluents generated in the Brazilian Northeastern region.

\section{Electrochemistry for environmental protection}

Electrochemistry can offer much for solving or alleviating environmental problems. Over the past 15 years, the electrochemical technology has been largely developed for its alternative use for wastewater remediation [32]. Oxidative electrochemical technologies, providing versatility, energy efficiency, amenability to automation, environmental compatibility and cost ef- fectiveness have reached a promising stage of development and can now be effectively used for the destruction of toxic or biorefractory organics [32-36].

Nowadays, the aquatic environment can be polluted by organic and inorganic chemicals from municipal and industrial sources. Some pollutants are usually controlled by means of biological treatments of wastewater [32, 33]. However, several advanced oxidation processes have been proposed as new strategies for treating industrial and domestic effluents. Recently, with the development of new process with less harmful effects, the suitability and efficiency of electrochemical technologies have increased [32-36].

In this frame, the electrochemistry offers two options for the treatment of these effluents containing with pollutants, with the aim of oxidizing them, not only to $\mathrm{CO}_{2}$ and $\mathrm{H}_{2} \mathrm{O}$, but to biodegradable products by direct and mediated electrochemical oxidation $[32,34]$ :

Electrochemical oxidation (EO), involving or not, heterogeneous species formed from water discharge, follows two approaches [20, 32-34]:

(i) Direct anodic oxidation (or direct electron transfer to the anode), which yields very poor decontamination.

(ii) Chemical reaction with electrogenerated species from water discharge at the anode such as physically adsorbed "active oxygen" (physisorbed hydroxyl radical $(\bullet \mathrm{OH})$ ) or chemisorbed "active oxygen" (oxygen in the lattice of a metal oxide (MO) anode). The action of these oxidizing species leads to total or partial decontamination, respectively.

Indirect electro-oxidation (IEO) involving the homogeneous reaction of organic pollutants with strong oxidants generated during electrolysis $[20,32,34]$ :

(i) The electro-oxidation with active chlorine, where direct anodic oxidation of chloride ion present in the effluent leads to the formation of free chlorine and/or chlorine-oxygen species that can oxidize organic pollutants in the bulk until overall mineralization.

(ii) The electro-Fenton process in which organics can be mineralized with homogeneous ' $\mathrm{OH}$ formed from Fenton's reaction between added catalytic $\mathrm{Fe}^{2+}$ and $\mathrm{H}_{2} \mathrm{O}_{2}$ electrogenerated from $\mathrm{O}_{2}$ reduction at a suitable cathode [36].

For case of indirect electrochemical oxidation, pollutants are also competitively destroyed by direct anodic oxidation and by reaction with heterogeneous ${ }^{\circ} \mathrm{OH}$ and other reactive oxygen species (ROS) and weaker oxidants produced from anodic oxidation of water and anions of the electrolyte.

The existence of indirect or mediated oxidation with different oxidant species has allowed the proposal of new alternatives for the pollution abatement in wastewaters.

\section{Applicability of electrochemical technologies for treating Brazilian industrial effluents}

\subsection{Petrochemical effluents}

Few reports have been published by Brazilian researchers concerning the application of electrochemical technologies for treatment of petrochemical effluents $[13,14]$. Table 1 summa- 
rizes the results obtained by them for electrochemical depuration of petrochemical effluents, and these are compared with the results report by Rajkumar et al. [12] (one of the first reports about this topic). An inspection of Table 1 corroborates the great mineralization attained for petroleum pollutants by using electrochemical treatment with different anodes. However, Northeastern Brazilian research groups are recently working in the applicability of these electrochemical technologies due to this region is one of the most important regions of petroleum exploration [13, 15-19]. For example, Santos et al. [13] investigated the electrochemical remediation of oil extraction industry wastewater using $\mathrm{Ti} / \mathrm{Ru}_{0.34} \mathrm{Ti}_{0.66} \mathrm{O}_{2}$ anode. The authors obtained the best COD reduction $(57 \%)$ of an oily sample for $70 \mathrm{~h}$ at $50^{\circ} \mathrm{C}$ with a current density of $100 \mathrm{~mA} \mathrm{~cm}^{-2}$ [13], but the slow rate of COD reduction could be attributed to the occurrence of secondary reactions involving $\mathrm{O}_{2}, \mathrm{Cl}_{2}$ and $\mathrm{H}_{2}$ evolution. Also, $24 \%, 48 \%$ and $57 \%$ COD reduction after $70 \mathrm{~h}$ of electrolysis at $10{ }^{\circ} \mathrm{C}, 25^{\circ} \mathrm{C}$ and $50{ }^{\circ} \mathrm{C}$ were achieved, respectively.

Zanbotto Ramalho et al. [15] studied the anodic oxidation of organic pollutants from PW generated by petroleum exploration of the Petrobras plant-Brazil using an electrochemical reactor with a $\mathrm{Ti} / \mathrm{RuO}_{2}-\mathrm{TiO}_{2}-\mathrm{SnO}_{2}$ electrode (Fig. 1). Under galvanostatic conditions $\left(\mathrm{j}=89 \mathrm{~mA} \mathrm{~cm}^{-2}\right)$, it was found that the organic pollutants degradation, using different flow rates $(0.25$, $0.5,0.8$ and $1.3 \mathrm{dm}^{3} / \mathrm{h}$ ), achieved distinct removal efficiencies (98\%, 97\%, 95\% and $84 \%$ were achieved, respectively). Significantly, under the same conditions, electrochemical process achieved poor degradation of phenol and ethyl benzene: $20-47 \%$ (at $0.25,0.8$ and $1.3 \mathrm{dm}^{3} / \mathrm{h}$ ) and $17-47 \%$ (at 0.25 , $0.5,0.8 \mathrm{dm}^{3} / \mathrm{h}$ ), respectively. Complete elimination of pollutants was obtained after $0.5-2.5 \mathrm{~h}$ of electrolysis (Fig 1), with energy consumption values ranging from 4.84 to $0.97 \mathrm{kWh}$ $\mathrm{m}^{-3}$ and removal prices from 0.14 to 0.61 US\$ (from 0.11 to 0.5 Euros).

Bezerra Rocha et al. [16] investigated the anodic oxidation of real PW, generated by petroleum exploration of the Petrobras plant from Brazil, using platinum supported on $\mathrm{Ti}(\mathrm{Ti} / \mathrm{Pt})$ and boron-doped diamond (BDD) anodes in an electrolytic batch cell. The influence of several operating parameters such as current, supporting electrolyte, agitation rate and temperature

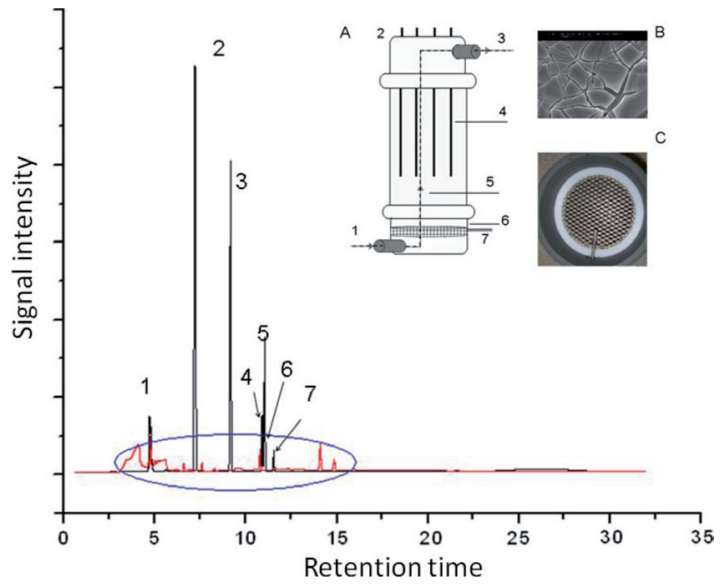

Figure 1. Organic pollutants removal from produced water by controlled current density electrolysis $\left(89 \mathrm{~mA} \mathrm{~cm}^{-2}\right)$ : initial sample (black line) and after EO process (red line). Experimental conditions: $25^{\circ} \mathrm{C}$; electrode area $19 \mathrm{~cm}^{2}, \mathrm{NaCl}: 15,000 \mathrm{mg} \mathrm{dm}^{-3}, \mathrm{pH}: 6.86$, flow rate: (A) $0.25 \mathrm{dm}^{3} / \mathrm{h}$. Symbols: (1) phenol; (2) benzene; (3) toluene; (4) ethyl benzene; (5) $o$-xylene; (6) $m$-xylene and (7) $p$-xylene. Produced water samples contain approximately $20-30 \mathrm{mg} \mathrm{dm}^{-3}$ of benzene, toluene, ethyl benzene, xylenes, and $5 \mathrm{mg} \mathrm{dm}^{-3}$ of phenol. Inset: (A) electrochemical reactor: (1) electrolyte inlet; (2) cathodic electric contacts; (3) electrolyte outlet; (4) stainless steel AISI 304 bars as cathodes; (5) flow direction; (6) anode and (7) electric anode contact. (B) $\mathrm{MeV}$ image of $\mathrm{Ti} / \mathrm{RuO}_{2}-\mathrm{TiO}_{2}-\mathrm{SnO}_{2}$ anode. (C) Image of mesh anode. Adapted from [15].

on the performance was studied and the energy consumption was also evaluated. Results clearly showed that BDD promotes complete COD removal (98\%) due to the high amounts of effective hydroxyl radicals and peroxodisulfates generated from water oxidation. COD removal rate increased notoriously when an increase on the current density (from 15 to $60 \mathrm{~mA} \mathrm{~cm}{ }^{-2}$ ) was applied (Figure 2a). Conversely, at Pt electrode, about 50\% of COD removals were achieved by applying 15 and $30 \mathrm{~mA}$ $\mathrm{cm}^{-2}$ of current density, and $80 \%$ of COD removal at $60 \mathrm{~mA}$ $\mathrm{cm}^{-2}$. When GC-MS analysis was performed to determine the concentration of the principal petroleum hydrocarbons eliminated; a comparison between the elimination of these organic pollutants as a function of applied current densities (15 and

Table 1. Removal efficiencies and energy consumption for electrochemical treatment of petrochemical effluents with different anodes.

\begin{tabular}{|c|c|c|c|c|c|c|c|}
\hline $\begin{array}{l}\text { Anode used* } \\
\text { wastewater }\end{array}$ & $C_{0} / \mathrm{mg} \mathrm{dm}^{-3}$ & $j^{\mathrm{d}} / \mathrm{mA} \mathrm{cm}^{-2}$ & $\begin{array}{c}\text { Electrolysis } \\
\text { time } / \mathrm{h}\end{array}$ & $\begin{array}{c}\text { Current } \\
\text { efficiency } / \%\end{array}$ & COD decay $/ \%$ & $\begin{array}{c}\text { Energy } \\
\text { consumption/Cost }\end{array}$ & Ref. \\
\hline \multicolumn{8}{|l|}{$\mathrm{Ti} / \mathrm{TiO}_{2}-\mathrm{RuO}_{2}-\mathrm{IrO}_{2}$} \\
\hline Oil refinery & $\begin{array}{l}602^{\mathrm{a}} \\
141^{\mathrm{b}} \\
112^{\mathrm{c}}\end{array}$ & 40 & 20 & 7.5 & 92 & $105.8 \mathrm{kWh} \mathrm{m}^{-3}$ & [12] \\
\hline \multicolumn{8}{|l|}{$\mathrm{Ti} / \mathrm{Ru}{ }_{0.34} \mathrm{Ti}_{0.66} \mathrm{O}_{2}$} \\
\hline \multicolumn{8}{|l|}{$\mathrm{Ti} / \mathrm{RuO} \mathrm{O}_{2}-\mathrm{TiO}_{2}$} \\
\hline Produced water & $1.8^{\mathrm{b}}$ & $8.6-17.8$ & 2 & 65 & 87 & $-\mathrm{e}$ & [14] \\
\hline
\end{tabular}

${ }^{\mathrm{a}}$ Initial COD $\left(\mathrm{mg} \mathrm{L}^{-1}\right) ;{ }^{\mathrm{b}}$ Phenolics initial concentration $\left(\mathrm{mg} \mathrm{L}^{-1}\right) ;{ }^{\mathrm{c}}$ Chloride dissolved $\left(\mathrm{mg} \mathrm{L}^{-1}\right) ;{ }^{\mathrm{d}}$ Applied current density; ${ }^{\mathrm{e}}$ Not determined. 
$30 \mathrm{~mA} \mathrm{~cm}$ ) and experimental conditions (real discharged conditions, $\mathrm{Na}_{2} \mathrm{SO}_{4}$ dissolved in the effluent and temperature) demonstrated that more than $95 \%$ of the organic compounds were completely oxidized as well as heavy metals were removed [16]. However, higher energy consumption and longer process time were accomplished, limiting the applicability of this technology for complete treatment of petrochemical wastewaters (Figure $2 b$ ).

On the other hand, a study has evaluated the efficiency of $\mathrm{Ti} / \mathrm{RuO}_{2}$ anode in degrading organic substances, present in wastewaters from petroleum industry, before their discharge or reuse [17] using an electrochemical flow reactor with higher anode area (Fig. 3). The COD removals, after 120 min of electrolysis, with a current density of $10 \mathrm{~mA} \mathrm{~cm}{ }^{-2}$, anodic area of $107 \mathrm{~cm}^{2}$, flow rate of $0.54 \mathrm{~mL} \mathrm{~s}^{-1}$ and at $25^{\circ} \mathrm{C}$, were above $96 \%$, for effluent after flotation, with $712 \mathrm{mg} \mathrm{L}^{-1} \mathrm{COD}$, and $87 \%$ for effluent before flotation, with $833 \mathrm{mg} \mathrm{L}^{-1}$ COD. Partial COD removal from both effluents was achieved when current density was increased from 10 to $30 \mathrm{~mA} \mathrm{~cm}{ }^{-2}$. The increase of current density also favored a decrease of the electrolysis time necessary to achieve a complete COD removal from both effluents. However, current density increase also led to higher specific energy consumption. For example, for the effluent
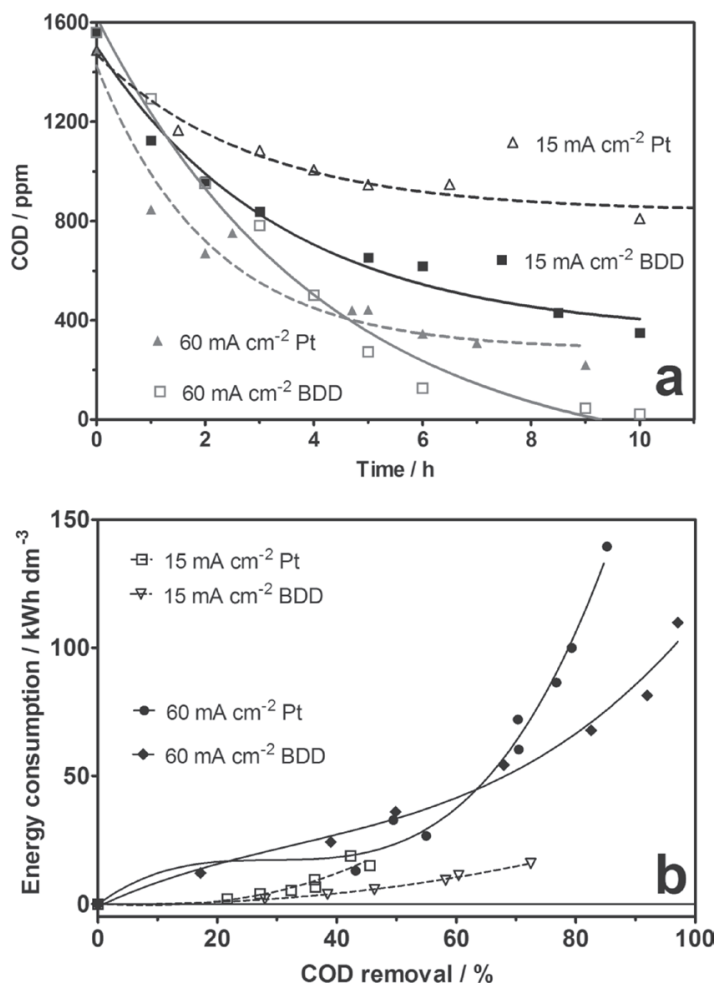

Figure 2. (a) Comparison of the COD decay, as a function of time, between Pt and BDD anodes during electrochemical treatment of PW containing with $5 \mathrm{~g}$ of $\mathrm{Na}_{2} \mathrm{SO}_{4}$ dissolved by applying 15 and $60 \mathrm{~mA}$ $\mathrm{cm}^{-2}$ of current density at $60{ }^{\circ} \mathrm{C}$. (b) Evolution of the energy consumption against $\%$ of COD removal during electrochemical treatment of petrochemical wastewater on Pt and BDD anodes. Conditions: applied current density: 15 and $60 \mathrm{~mA} \mathrm{~cm}^{-2} ; \mathrm{T}=60^{\circ} \mathrm{C}$; agitation rate: $400 \mathrm{rpm}$ and $5 \mathrm{~g}$ of $\mathrm{Na}_{2} \mathrm{SO}_{4}$ dissolved in PW effluent. Adapted from [16]. before flotation treatment, the cost of the energy necessary to achieve a complete COD removal in $60 \mathrm{~min}$ was around $38 \mathrm{US} \$ \mathrm{~kg}_{\mathrm{COD}}{ }^{-1}$ (28.5 Euros $\mathrm{kg}_{\mathrm{COD}^{-1}}{ }^{-1}$ ), while that for effluent after flotation treatment, under similar conditions after $30 \mathrm{~min}$ of electrolysis was only $28 \mathrm{US} \$ \mathrm{~kg}_{\mathrm{COD}}{ }^{-1}$ (21 Euros $\mathrm{kg}_{\mathrm{COD}}{ }^{-1}$ ). Results showed that $\mathrm{Ti} / \mathrm{RuO}_{2}$ electrode can be an efficient alternative for the treatment of effluents containing residues of petroleum and petroleum products [17].

Recently, the scale-up of electrochemical flow system was investigated by treating petrochemical wastewater using $\mathrm{Ti} / \mathrm{Pt}$ and BDD anodes by Santos et al. [18]. An electrochemical flow cell was used in order to find the best condition for the anodic treatment of the petrochemical wastewater (employing the PW samples as received from petrochemical industry). Preliminary experiments were performed at $25^{\circ} \mathrm{C}$ for studying the role of anode material (Ti/Pt and BDD anodes with $63.5 \mathrm{~cm}^{2}$ ) and applied current density $\left(j=20,40\right.$ and $\left.60 \mathrm{mAcm}^{-2}\right)$. Results clearly indicated that higher COD removals were achieved at different applied current densities, using Ti/Pt and BDD anodes. At 20, 40 and $60 \mathrm{mAcm}^{-2}$ using Ti/Pt electrode, $64.5 \% 90.7 \%$ and $93.6 \%$ of COD removals were achieved, respectively (Fig. 4a). Under similar conditions, at BDD anode, $76.2 \%, 94.5 \%$ and $97.1 \%$ of COD elimination were obtained in $8 \mathrm{~h}$ of treatment (Fig. 4b). Total current efficiencies were estimated by applying 20, 40 and $60 \mathrm{mAcm}^{-2}$, for Pt anode, achieving 58\%, 41\% and $29 \%$; whereas at BDD anode, $70 \%, 54 \%$ and $39 \%$ were attained, respectively. These values confirm that an amount of current is employed in oxygen evolution reaction (undesired reaction) after the first hours of treatment, decreasing the total efficiency of electrochemical oxidation reaction. The effect of temperature during the electrochemical treatment of petrochemical effluent (employing the PW samples as received) was also studied by applying $40 \mathrm{~mA} \mathrm{~cm}$, varying the temperature $\left(25,40\right.$ and $\left.60^{\circ} \mathrm{C}\right)$. These temperatures were selected; because these mimic the real temperatures of the petroleum platform discharges. It was observed that changes in temperature have a strong influence on oxidation rate by applying $40 \mathrm{~mA} \mathrm{~cm}{ }^{-2}$ at $\mathrm{Ti} / \mathrm{Pt}$ anode, reducing treatment times. COD removals after $5 \mathrm{~h}$ of treatment were of $83.2 \%, 87.4 \%$ and $92.1 \%$ at $\mathrm{Ti} / \mathrm{Pt}$; while for BDD the influence on temperature contributes with a modest increase on oxidation rate, COD removals of $81.9 \%$, $91.8 \%$ and $94.5 \%$ were achieved.

It is important to remark that, under high concentrations of $\mathrm{NaCl}$ in solution (a key characteristic of petrochemical effluents) $\mathrm{EO}$ via ${ }^{\bullet} \mathrm{OH}$ radicals is not the only oxidation mechanism that occurs on electrochemical treatment. In this case, chlorohydroxyl radicals are also generated on anode surface, and consequently oxidizing organic matter. Therefore, Da Silva et al. [19] studied the anodic oxidation of three classes of produced water (PW) (fresh, brine and saline) generated by petrochemical industry using $\mathrm{Ti} / \mathrm{IrO}_{2}-\mathrm{Ta}_{2} \mathrm{O}_{5}$ and BDD electrodes in a flow reactor. Different types of PW found in oilfields: fresh, brine and saline, which are assigned to the direct influence of the characteristics of the soil where they are confined. During electrochemical treatment, various operating parameters were investigated, such as temperature, $\mathrm{pH}$, conductivity, current 

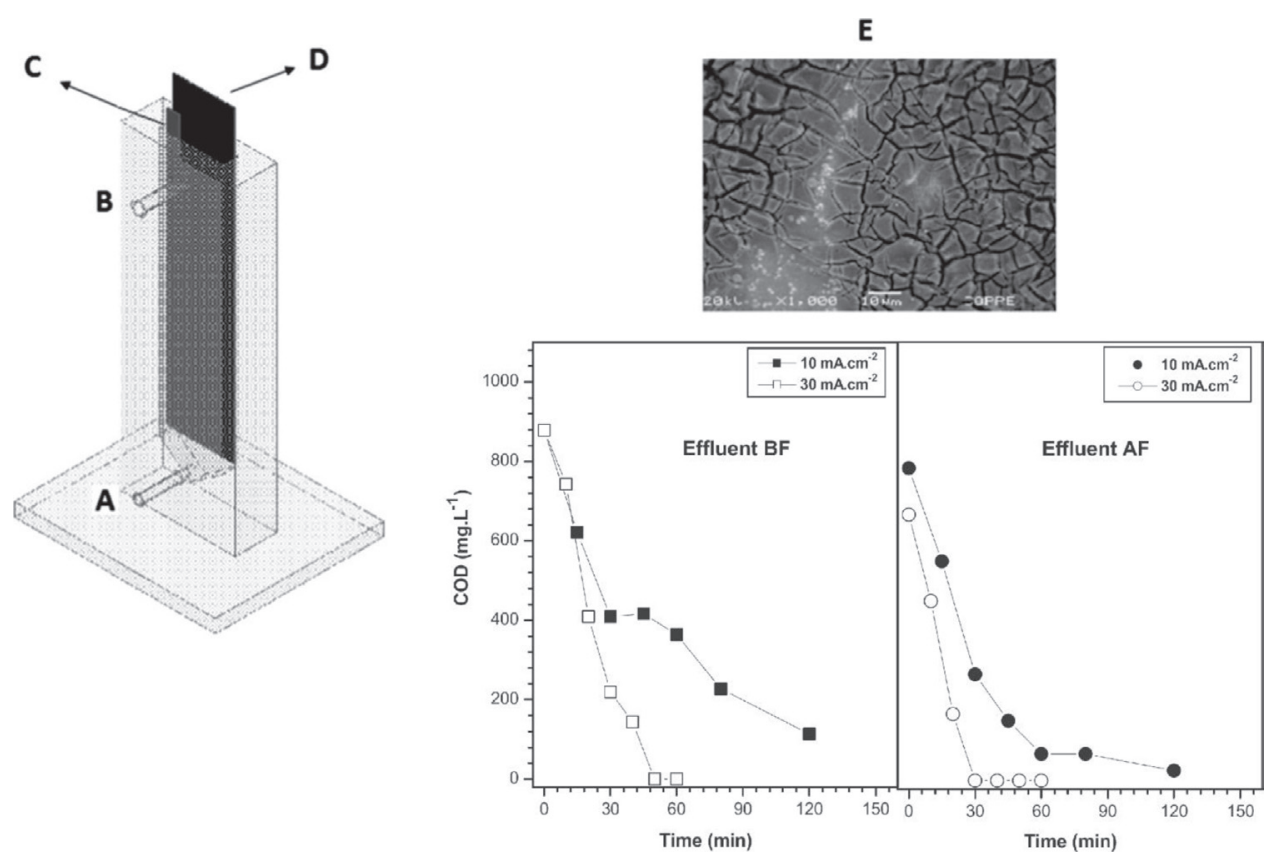

Figure 3. Scheme of the electrolytic cell used in the experiments. A) effluent entrance; B) effluent exit; C) cathode: titanium plate; D) anode: $\mathrm{Ti} / \mathrm{RuO}_{2}$ plate; E) SEM micrographs of $\mathrm{Ti} / \mathrm{RuO}_{2}$ anode. Graphics: Influence of electrolysis time on COD removal from effluents before filtration (BF) and after filtration (AF) for different current densities. Anodic area: $107 \mathrm{~cm}^{2}$, flow rate: $0.54 \mathrm{~mL} \mathrm{~s}$, $25^{\circ} \mathrm{C}$. Adapted from [17].
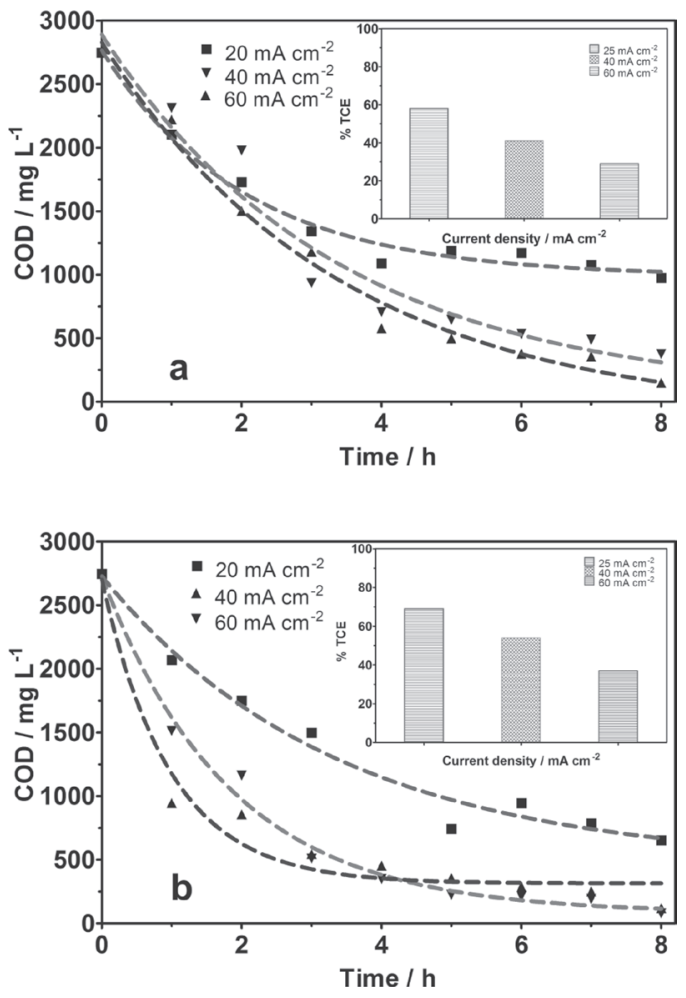

Figure 4. Influence of applied current density on the COD removal as a function of time and total current efficiency (inset) during PW anodic oxidation using (a) Ti/Pt and (b) BDD anodes. Operating conditions: PW sample, as obtained from Brazilian platform, applied current density $=20,40$ and $60 \mathrm{~mA} \mathrm{~cm}^{-2}, 25^{\circ} \mathrm{C}$, flow rate: $151 \mathrm{~L} \mathrm{~h}^{-1}$. Adapted from [18]. density, total organic carbon (TOC), chemical oxygen demand (COD) as well as energy consumption and cost. The use of these electrode materials was proposed by them because the electrocatalytic features to produce in-situ-strong oxidant species, principally active chlorine, is a key point that must be investigated to propose the applicability of this method as a pre-treatment process for the petrochemical industry.

To understand the performance of the electrochemical treatment, mainly due to different concentrations of chloride ions, different applied current densities were used for each type of PW (fresh, brine and saline), evaluating the efficiency of the anode materials ( $\mathrm{Ti} / \mathrm{IrO}_{2}-\mathrm{Ta}_{2} \mathrm{O}_{5}$ and BDD) [19]. In the case of fresh PW, results clearly demonstrated that when lower current densities were applied, lower Q was employed, avoiding a complete elimination of COD, principally when $\mathrm{Ti} / \mathrm{IrO}_{2}-\mathrm{Ta}_{2} \mathrm{O}_{5}$ was used as electrocatalytic material (Fig. 5a). Conversely, when BDD anode was employed, lower Q was necessary to achieve a significant COD removal by applying 2.5 and $5 \mathrm{~mA} \mathrm{~cm}^{-2}$ (Fig. $5 b)$. Higher TOC removal efficiencies were achieved on BDD (ranging from $40 \%$ to $90 \%$ ) respect to the $\%$ TOC removals obtained at $\mathrm{Ti} / \mathrm{IrO}_{2}-\mathrm{Ta}_{2} \mathrm{O}_{5}$.

For brine PW, results showed that the COD decay, at different applied current density $\left(10,20\right.$, and $\left.30 \mathrm{~mA} \mathrm{~cm}^{-2}\right)$ for $\mathrm{Ti} / \mathrm{IrO}_{2}-\mathrm{Ta}_{2} \mathrm{O}_{5}$ and $\mathrm{BDD}$ anodes, depends on applied current density as well as the Q (Fig. 6a). Complete COD removal was achieved by applying $30 \mathrm{~mA} \mathrm{~cm}{ }^{-2}$ at $\mathrm{Ti} / \mathrm{IrO}_{2}-\mathrm{Ta}_{2} \mathrm{O}_{5}$, after approximately $240 \mathrm{~min}$ of electrolysis $\left(\approx 6 \mathrm{Ah} \mathrm{dm}^{-3}\right.$, see Fig. $6 a)$, while at 10 and $20 \mathrm{~mA} \mathrm{~cm}^{-2}$, a partial COD removal was achieved, about 71.5\% $\left(2 \mathrm{Ah} \mathrm{dm}^{-3}\right)$ and 78.6\% $\left(4.2 \mathrm{Ah} \mathrm{dm}^{-3}\right)$, 

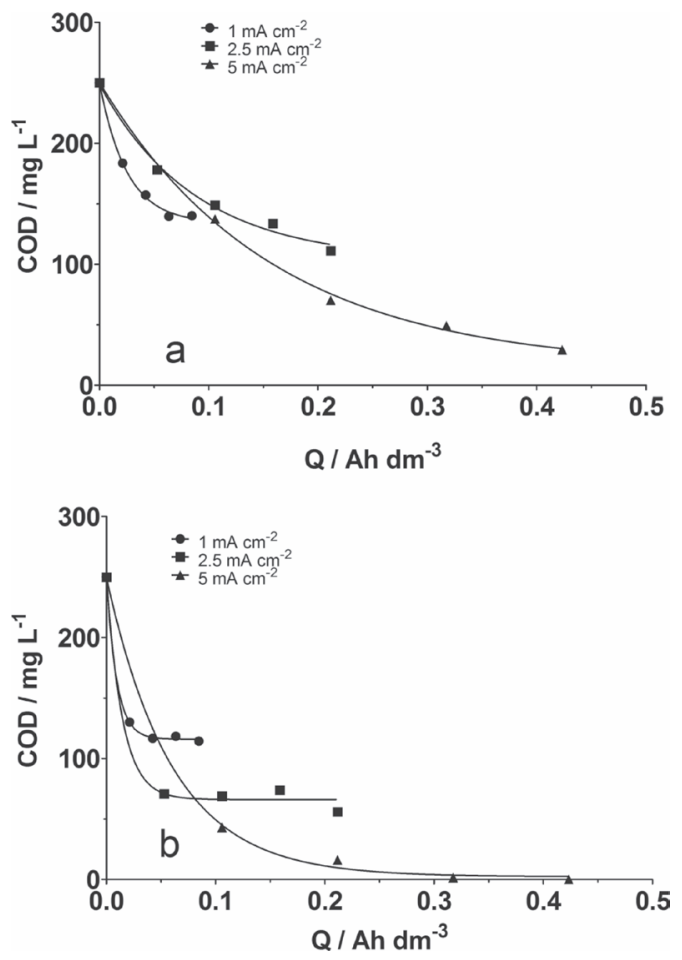

Figure 5. Influence of applied current density on COD removal, as a function of $\mathrm{Q}$, during fresh $\mathrm{PW}$ electrolysis at $25^{\circ} \mathrm{C}$ using $\mathrm{Ti} / \mathrm{IrO}_{2^{-}}$ $\mathrm{Ta}_{2} \mathrm{O}_{5}$ (a) and BDD (b) anodes. Operational conditions: Flow rate $=160 \mathrm{dm}^{3} \mathrm{~h}^{-1}$ and different applied current densities: $1 \mathrm{~mA} \mathrm{~cm} \mathrm{~cm}^{-2}$ (circle), $2.5 \mathrm{~mA} \mathrm{~cm}^{-2}$ (square), and $5 \mathrm{~mA} \mathrm{~cm}^{-2}$ (triangle). Adapted from [19].

respectively. However, TOC results indicated that the effluent seems to have some recalcitrant compounds (or degradation products) that are not oxidized under these experimental conditions. For BDD anode, under the same experimental conditions, complete COD removal was achieved at all current densities (after $1.7 \mathrm{Ah} \mathrm{dm}^{-3}\left(10 \mathrm{~mA} \mathrm{~cm}{ }^{-2}\right), 3 \mathrm{Ah} \mathrm{dm}^{-3}\left(20 \mathrm{~mA} \mathrm{~cm}^{-2}\right)$ and $4 \mathrm{Ah} \mathrm{dm}^{-3}\left(30 \mathrm{~mA} \mathrm{~cm}^{-2}\right)$, see Fig. 6b), decreasing remarkably the electrolysis time. Considering that, the effluent had higher concentrations of $\mathrm{Cl}^{-}$in solution; it promoted the production of active chlorine species and consequently, favoring a faster COD abatement [19]. Also, TOC removals ranged from 92 to $99 \%$, indicating that the degradation process occurs with no significant formation of recalcitrant intermediates.

During the electrochemical treatment of saline PW using $\mathrm{Ti} / \mathrm{IrO}_{2}-\mathrm{Ta}_{2} \mathrm{O}_{5}$ and $\mathrm{BDD}$ electrodes at $25^{\circ} \mathrm{C}$ was observed that at both materials, COD decay was slight after $8 \mathrm{~h}$ of electrochemical treatment, independent on applied current density (10 $\mathrm{mA} \mathrm{cm}{ }^{-2}$ or $20 \mathrm{~mA} \mathrm{~cm}^{-2}$ ). Results clearly showed that a modest anodic oxidation of saline PW was performed, achieving $50 \%$ of COD removal by applying 10 and $20 \mathrm{~mA} \mathrm{~cm}{ }^{-2}$, at $\mathrm{Ti} / \mathrm{IrO}_{2}-$ $\mathrm{Ta}_{2} \mathrm{O}_{5}$ electrode after 3.5 and $7 \mathrm{Ah} \mathrm{dm}^{-3}$, respectively (Fig. 7a). The mineralization rate (TOC removal $(\approx 37 \%)$ ) was not significantly influenced by the higher concentrations of chloride in the petrochemical effluent, suggesting that the production of $\mathrm{Cl}_{2}$ is the preferential reaction. Likewise, for BDD anode, the COD removal, under similar conditions, occurs with similar
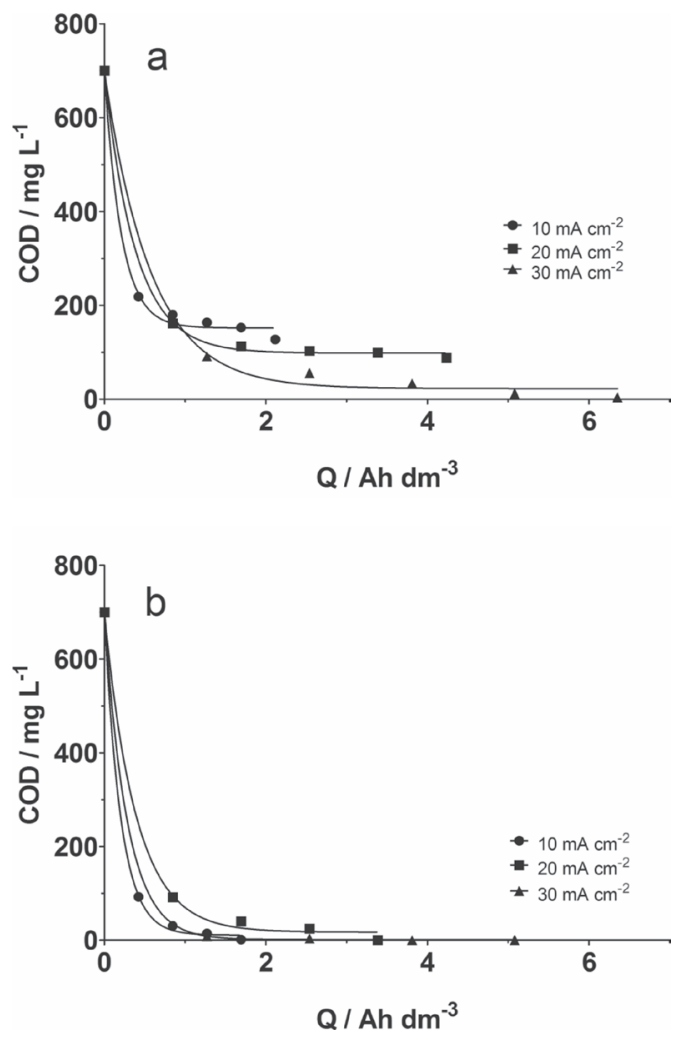

Figure 6. Influence of applied current density on COD removal, as a function of Q, during brine $\mathrm{PW}$ electrolysis at $25^{\circ} \mathrm{C}$ for $\mathrm{Ti} / \mathrm{IrO}_{2}-\mathrm{Ta}_{2} \mathrm{O}_{5}$ (a) and BDD (b) anodes. Operational conditions: Flow rate $=160 \mathrm{dm}^{3}$ $\mathrm{h}^{-1}$ and different applied current densities: $10 \mathrm{~mA} \mathrm{~cm}^{-2}$ (circle), $20 \mathrm{~mA}$ $\mathrm{cm}^{-2}$ (square) and $30 \mathrm{~mA} \mathrm{~cm}^{-2}$ (triangle). Adapted from [19].

efficiencies than those achieved for $\mathrm{Ti} / \mathrm{IrO}_{2}-\mathrm{Ta}_{2} \mathrm{O}_{5}$ (Fig. 7b). On the other hand, $44 \%$ of COD removal was achieved for BDD independent on applied current density due to two features: higher $\mathrm{Cl}^{-}$concentrations $\left(86875 \mathrm{mg} \mathrm{dm}^{-3}\right)$ and higher initial COD $\left(11541 \mathrm{mg} \mathrm{dm}^{-3}\right)$. The degradation process when higher $\mathrm{Cl}^{-}$concentrations are present in the effluent, it occurs with significant formation of $\mathrm{Cl}_{2}$ gas in concomitance with higher production of $\mathrm{O}_{2}$, complicating the complete oxidation of organic matter. Also, higher initial COD is traduced in the production of several by-products decreasing the efficiency process and this assertion was in agreement with the TOC efficiencies obtained during electrochemical treatment of saline PW by applying 10 and $20 \mathrm{~mA} \mathrm{~cm}{ }^{-2}$ of current density [19].

\subsection{Textile effluents}

Electrochemical oxidation or electro-oxidation is one of main electrochemical procedures utilized for the remediation of dyestuffs wastewaters and in the last years, it has received great attention as alternative for decolorizing and degrading dyes from industrial effluents. Conversely to the research development to depuration of petrochemical effluents; the applicability of diverse electrochemical technologies for removing dyes from aquatic ecosystems has been the objective of several Brazilian groups. In the case of electrochemical oxidation, it is ascribed 

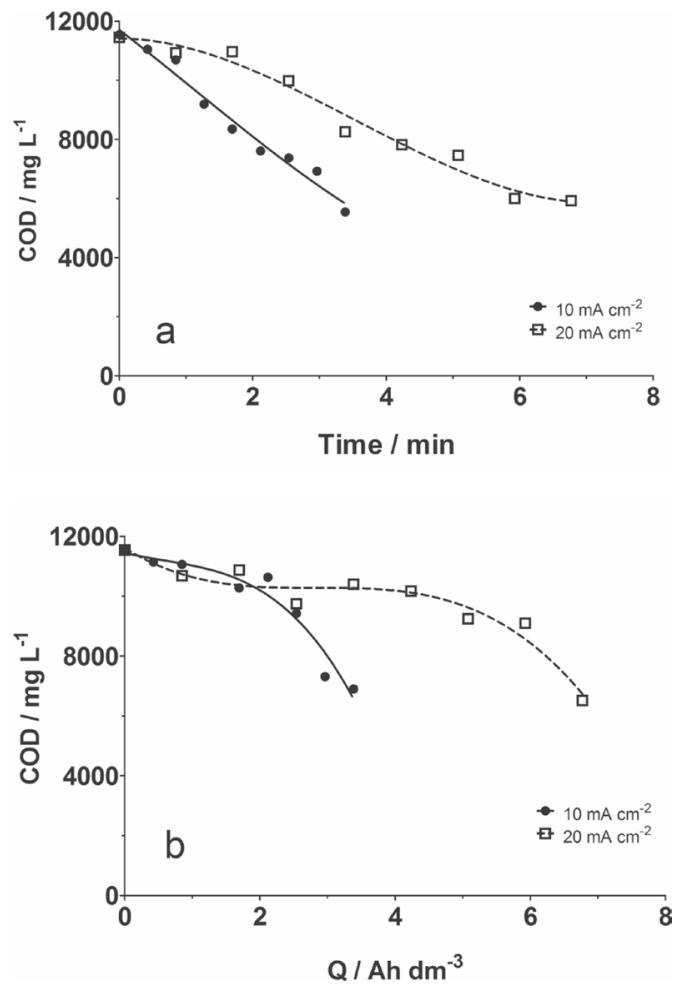

Figure 7. Influence of applied current density on COD removal, as a function of Q, during saline $\mathrm{PW}$ electrolysis at $25^{\circ} \mathrm{C}$ for $\mathrm{Ti} / \mathrm{IrO}_{2}-\mathrm{Ta}_{2} \mathrm{O}_{5}$ (a) and BDD (b) anodes. Operational conditions: Flow rate $=160 \mathrm{dm}^{3}$ $\mathrm{h}^{-1}$ and different applied current densities: $10 \mathrm{~mA} \mathrm{~cm}^{-2}$ (circle) and 20 $\mathrm{mA} \mathrm{cm}{ }^{-2}$ (square). Adapted from [19].

to the high and indiscriminate reactivity of hydroxyl radicals, which are produced when water is oxidized at the anode surface. Theoretically, based on the existing literature [20, 32-36], nonactive anodes [28, 32, 34], like $\mathrm{PbO}_{2}$ and boron doped diamond (BDD) electrodes, are the anode materials that have higher oxidation power thanks to the great property to produce higher concentrations of hydroxyl radicals. Consequently, BDD anode has been selected by us for treating real textile wastes.

The first study showed that the electrochemical treatment of synthetic dye (Remazol Red BR (RRB) and Novacron Blue C-D (NB)) effluents was efficiently performed by using BDD [37]. Color and COD were successfully removed from wastewaters polluted with synthetic textile dyes, under specific operating conditions (current density, $\mathrm{pH}$ and temperature). The influence of current density, temperature and $\mathrm{pH}$, as functions of time, during galvanostatic electrolyses of dye wastewaters, showed that oxidation by the electrogenerated reagents from the anodic oxidation of supporting electrolyte (e. g.: ${ }^{\bullet} \mathrm{OH}$ and peroxodisulphates) plays an important role in the efficiency of the electrochemical process. Energy consumption has been also measured during galvanostatic electrolysis of dye solutions, and it was demonstrated that it depends largely on the applied current density but was only modestly influence by temperature.

After the study about the application of the electrochemical oxidation of synthetic dyes wastewater RRB and NB using a
BDD anode; an effluent of an actual Brazilian textile industry was employed to assess the efficiency on electrochemical treatment using diamond electrode $\left(10 \mathrm{~cm}^{2}\right)$ as an alternative for removing organic matter and color [31]. Results showed that the decrease of the absorbance, as a function of time, during galvanostatic electrolysis of real textile effluent $(0.5 \mathrm{~L})$ was achieved after $12 \mathrm{~h}$ by applying $60 \mathrm{~mA} \mathrm{~cm}{ }^{-2}$ of current density under original discharged effluent conditions $(\mathrm{COD}=1,018$ $\mathrm{mg} \mathrm{dm}{ }^{-3}, 7128$ Hazen units, $25^{\circ} \mathrm{C}$ ). However, the Brazilian regulations for color removal were not attained under these circumstances because no more than partial color removal was achieved ( $\approx 21 \%$ (5940 Hazen units), due to the low conductivity of the effluent and higher organic pollutant concentrations (NB, RRB and amylum with different additives) dissolved in the effluent, which increases the decolourisation time treatment required for complete elimination. Additionally, COD was partially removed, decaying from $1,018 \mathrm{mg} \mathrm{dm}^{-3}$ to 890 $\mathrm{mg} \mathrm{dm}{ }^{-3}$, approximately $12.6 \%$. Nevertheless, when $\mathrm{Na}_{2} \mathrm{SO}_{4}$ was added in the effluent, color removal efficiency was significantly increased, achieving different values of $\mathrm{HU}(610,152$ and $0 \mathrm{HU}$ after $12 \mathrm{~h}$ of electrolysis, for 20,40 and $60 \mathrm{mAcm}^{-2}$, respectively). However, 40 and $60 \mathrm{mAcm}^{-2}$ showed fast decolourisation performances $(97.9 \%$ and $100 \%$ of color removal, respectively); attaining Brazilian regulations of color removal (under $300 \mathrm{HU}$ ) after 10 and $4 \mathrm{~h}$, respectively. Also, results clearly indicated that the highest COD removal was achieved at $60 \mathrm{mAcm}^{-2}$ after $12 \mathrm{~h}$ of electrolysis (100\% of COD removal) because this is consistent with the charged passed that favors the electrogeneration of more hydroxyl radicals on BDD surface [37, 22]. Conversely, at 20 and $40 \mathrm{~mA} \mathrm{~cm}^{-2}$, COD removal was not completed after $12 \mathrm{~h}$ of treatment, achieving $75 \%$ and $92 \%$ of COD removal, respectively.

In order to verify the importance of scale-up of the process, electrochemical treatment of a real effluent was performed by using a flow electrolytic cell [30]. On basis of the results obtained for anodic oxidation of a dyestuff effluent, the electrochemical technology can be suitable as an alternative for pre-treatment of textile real effluents under the real discharge conditions employed by the Brazilian textile industry (COD, $\mathrm{pH}=10$ and $60^{\circ} \mathrm{C}$ ) for complete COD and color removal. In fact, more than $70 \%$ of color removal was achieved after $7 \mathrm{~h}$ of treatment by applying 40 and $60 \mathrm{mAcm}^{-2}$. Also, COD results clearly indicated that the highest removal rate was achieved at 40 and $60 \mathrm{~mA} \mathrm{~cm}^{-2}$ because the greater charge passed that favored the electrogeneration of more hydroxyl radicals produced on BDD surface. Despite the complete COD decay occurs under last conditions, long times are required for complete removal, 19 and $17 \mathrm{~h}$, respectively. In contrast, incomplete COD removal was achieved by applying $20 \mathrm{~mA} \mathrm{~cm}{ }^{-2}$ after $23 \mathrm{~h}$. However, if an amount of $\mathrm{Na}_{2} \mathrm{SO}_{4}$ is added, the efficiency of the process can be strongly improved (Fig. 8). Color removal rate was significantly increased, achieving different values of efficiency $(95 \%$, $100 \%$ and $100 \%$ of color removal after $12 \mathrm{~h}, 8 \mathrm{~h}$ and $4 \mathrm{~h}$ of electrolysis, for 20,40 and $60 \mathrm{~mA} \mathrm{~cm}^{-2}$, respectively). On the other hand, an increase on COD removal, when sulphates were added in the effluent, was observed because the electrogenera- 
tion of peroxodisulphates avoid mass transport limitations and also the secondary reaction of oxygen evolution.

It is important to mention that in the Brazilian textile industry, complete COD and color removal are attained after 5 or 6 days of biological depuration together with a subsequent physical-chemical treatment (under specific $\mathrm{pH}$ and temperature conditions). Conversely, COD and color were efficiently reduced after $15 \mathrm{~h}$ of electrochemical process, attaining Brazilian legal requirements and maintaining the same discharged conditions with the addition of a small amount of $\mathrm{Na}_{2} \mathrm{SO}_{4}$; in consequence, the time treatment was reduced and costs, confirming the potential efficiency of the application of electrochemical treatment.

However, a new study concerning to the use of electrochemical approaches was performed to increase the understanding of real effluent treatment by involving the electrochemical production of reactive oxidant species, peroxodisulphates or active chlorine [29]. Many electrochemical studies for depuration of wastewaters containing dyes (dyes solutions, synthetic and real textile effluents) have been performed for studying the influence of chloride, sulphate and phosphate in the depuration rate process using different electrocatalytic materials [20].

In the case of elimination of organic matter by $\mathrm{Cl}$-mediated oxidation, this process can be more efficient when compared with direct electrochemical oxidation [32]. However, as previ-
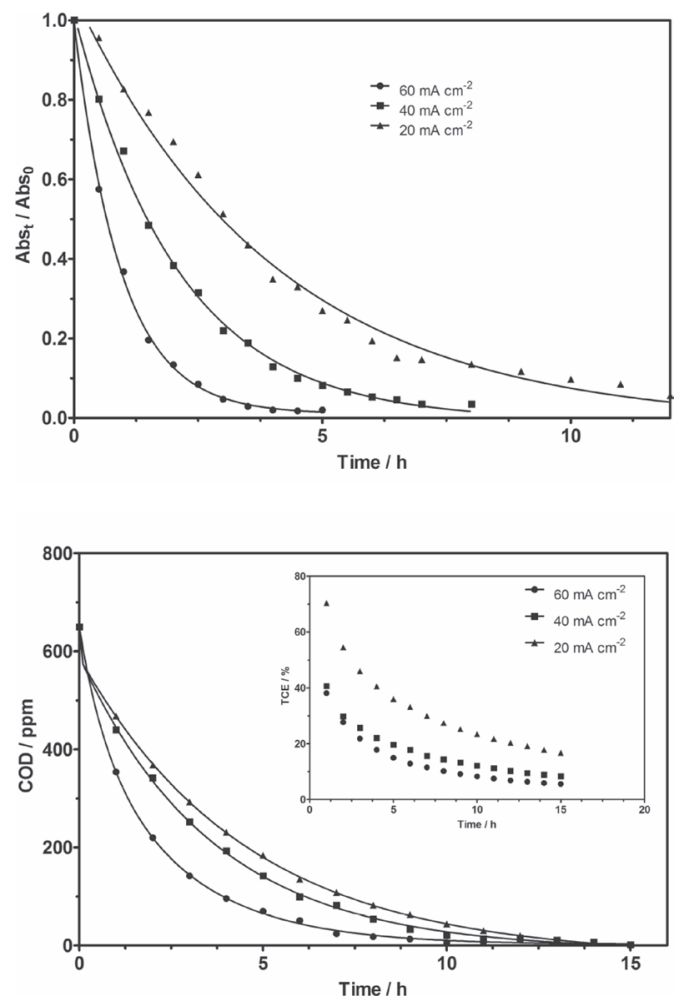

Figure 8. a) Colour removal of a real effluent, as a function of time, applying different current densities using BDD anode. b) Influence of applied current on the evolution of COD and total current efficiency (TCE, (inset)), as a function of time, during electrochemical treatment of actual textile using BDD anode. Experimental conditions: $\mathrm{T}=25^{\circ} \mathrm{C}$, $5 \mathrm{~g} \mathrm{dm}^{-3}$ of $\mathrm{Na}_{2} \mathrm{SO}_{4}$ and flow rate $=250 \mathrm{dm}^{3} \mathrm{~h}^{-1}$. Adapted from [30]. ously pointed out by De Battisti and his group [38] and Polcaro et al. [39], the electrochemical oxidation of organic compounds in presence of high concentrated chlorides may results in a positive effect (higher removal rate) or may be in a undesired generation of chlorinated by-products. Then, the study of intermediates formed during electrochemical treatment of a real effluent became a topic of great importance in our research.

In this study, the results clearly indicated that high COD removal was achieved, after adding $\mathrm{Na}_{2} \mathrm{SO}_{4}$ in the effluent, by applying $60 \mathrm{~mA} \mathrm{~cm}^{-2}$ after $12 \mathrm{~h}$ of electrolysis $(100 \%$ of COD removal). Conversely, at 20 and $40 \mathrm{~mA} \mathrm{~cm}{ }^{-2}$, COD removal was not completed after $12 \mathrm{~h}$ of treatment, achieving no more than $75 \%$ and $92 \%$ of COD removal, respectively. This behavior was principally attributed to an increase of the indirect reaction of organics with electrogenerated oxidizing agents from electrolyte oxidation; such as persulfates [29]. In the case of $\mathrm{NaCl}$, an amount of $5 \mathrm{~g}$ was added in the real effluent, analyzing the effect of applied current density by applying 20, 40 and 60 $\mathrm{mA} \mathrm{cm}{ }^{-2}$ at $25^{\circ} \mathrm{C}$. As it can be observed from Fig. 9 (curves b-d), when $\mathrm{NaCl}$ was added in the effluent, color removal efficiency was notably increased, decaying largely $\mathrm{HU}$ values than those obtained when $\mathrm{Na}_{2} \mathrm{SO}_{4}$ was employed $(200,25$ and $0 \mathrm{HU}$ after $6 \mathrm{~h}$ of electrolysis, for 20,40 and $60 \mathrm{~mA} \mathrm{~cm}{ }^{-2}$, respectively). Conversely to $\mathrm{Na}_{2} \mathrm{SO}_{4}$, Brazilian regulations about color removal (fewer than $300 \mathrm{HU}$ [29]) were attained, for all cases, after $6 \mathrm{~h}$ of treatment, when $\mathrm{NaCl}$ was used. These results were achieved due to the production of active chlorine species on BDD surface [32], favoring a quick elimination of color because these strong oxidant species rapidly attack the chromophore group [29]. In the case of elimination of organic matter, COD quickly decayed during $\mathrm{Cl}$-mediated oxidation of the real textile effluent on BDD anode, as a function of time, at $25^{\circ} \mathrm{C}$. Higher COD removal efficiencies were achieved at 20, 40 and $60 \mathrm{~mA} \mathrm{~cm}{ }^{-2}$ of current density. Conversely to $\mathrm{Na}_{2} \mathrm{SO}_{4}$, before $10 \mathrm{~h}$ of electrolysis, more than $95 \%$ of COD removal was achieved, in all cases, achieving a lower charge consumed for complete mineralization. However, restricting now our analysis to the intermediates produced during electrochemical treatment by persulfates or active chlorine, GC/MS analysis revealed the presence of chloroform. From the data reported in Table 2, we can infer that when an increase on the concentration of chloride ions in solution was achieved, higher COD removal efficiencies were obtained, but an increase in formation of chloroform was accomplished. Considering that $50 \mathrm{ppm}$ is the permissible exposure limit [35], only for lower concentrations of $\mathrm{NaCl}$ no traces of chloroform were detected. Conversely, using $\mathrm{Na}_{2} \mathrm{SO}_{4}$, no production of organochloride compounds was achieved, obtaining higher COD removal efficiencies.

\section{Conclusions and future directions}

The results of our investigations demonstrated that anodic oxidation can be used successfully to remove completely organic pollutants from petrochemical wastewaters and textile effluents. In the case of petrochemical effluents, the efficiency decontamination and time process depend on the operating conditions, such as current density, electrolyte, temperature 


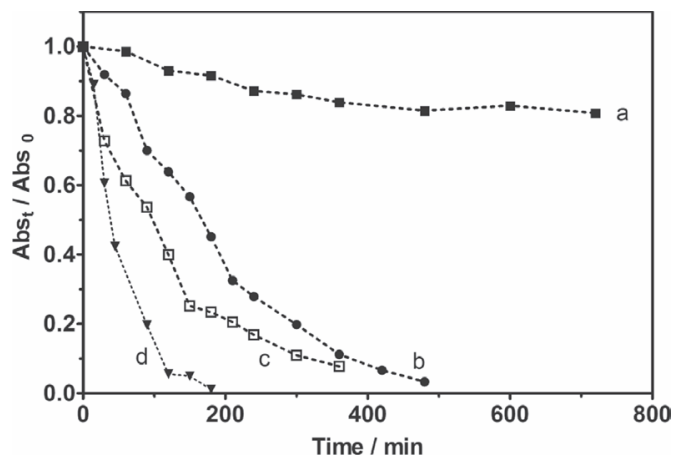

Figure 9. Electrochemical decolourisation process of a real effluent, as a function of time, applying different current densities values at $25^{\circ} \mathrm{C}$ (curve a: $60 \mathrm{~mA} \mathrm{~cm}^{-2}$, effluent as obtained; curve b: $20 \mathrm{~mA} \mathrm{~cm}{ }^{-2}, 5 \mathrm{~g}$ of $\mathrm{NaCl}$; curve c: $40 \mathrm{~mA} \mathrm{~cm}{ }^{-2}, 5 \mathrm{~g}$ of $\mathrm{NaCl}$ and curve $\mathrm{d}: 60 \mathrm{~mA} \mathrm{~cm}^{-2}$, $5 \mathrm{~g}$ of $\mathrm{NaCl}$. Adapted from [29].

and nature of material. Although the electrical dependence and process time could make useless the electrochemical approach for complete treatment of petrochemical wastewaters; it can be a feasible process as a pre-treatment process reducing significantly the cost and time treatment. Electrochemical oxidation system could be scaled up as large as required without performance deterioration by increasing the total anode area and modifying the hydrodynamic configuration of cell.

For the electrochemical approaches for treating textile effluents, it can be suitable as an alternative for pre-treatment under the real discharge conditions $(\mathrm{COD}, \mathrm{pH} 10$ and temp $=$ $60^{\circ} \mathrm{C}$ ) without the addition of a small amount of $\mathrm{Na}_{2} \mathrm{SO}_{4}$ or Na$\mathrm{Cl}$. However, the mediated electrochemical approach (perox-

Table 2. Production of chloroform during electrochemical oxidation of real textile effluent using different $\mathrm{Na}_{2} \mathrm{SO}_{4}$ and $\mathrm{NaCl}$ concentrations.

\begin{tabular}{|c|c|c|}
\hline $\mathrm{Na}_{2} \mathrm{SO}_{4}\left(\mathrm{~g} \mathrm{~L}^{-1}\right) / \mathrm{mol} \mathrm{L}^{-1}$ & $\%$ COD removal $^{\mathrm{a}}$ & Chloroform $/ \mathrm{mg} \mathrm{L}^{-1}$ \\
\hline $0 / 0.000$ & 12.5 & $-b$ \\
\hline $1 / 0.007$ & 98 & $-b$ \\
\hline $2 / 0.014$ & 100 & $-b$ \\
\hline $5 / 0.035$ & 100 & $-b$ \\
\hline $10 / 0.070$ & 100 & $-b$ \\
\hline $20 / 0.141$ & 100 & $-b$ \\
\hline $30 / 0.211$ & 100 & $-b$ \\
\hline $\mathrm{NaCl}\left(\mathrm{g} \mathrm{L}^{-1}\right) / \mathrm{mol} \mathrm{L}^{-1}$ & $\% \mathrm{COD}_{\text {removal }}^{\mathrm{a}}$ & Chloroform $/ \mathrm{mg} \mathrm{L}^{-1}$ \\
\hline $0 / 0.000$ & 12.5 & $-b$ \\
\hline $1 / 0.0107$ & 80 & $-b$ \\
\hline $2 / 0.034$ & 95 & 45.0 \\
\hline $5 / 0.086$ & 100 & 65.6 \\
\hline $10 / 0.171$ & 100 & 83.6 \\
\hline $20 / 0.341$ & 100 & 126.9 \\
\hline $30 / 0.513$ & 100 & 150.1 \\
\hline
\end{tabular}

${ }^{\text {a }}$ Removal efficiencies achieved at $25{ }^{\circ} \mathrm{C}$ and $40 \mathrm{~mA} \mathrm{~cm}^{-2}$.

${ }^{b}$ Not detected. odisulphates and active chlorine production) can be considered more effective than the direct one, because of the minor problems of electrode fouling and/or corrosion. In contrast, each effluent is different, for that reason, when different dosages of $\mathrm{NaCl}$ are used; different chloroform concentrations could be produced and detected. Perhaps the production of undesired byproducts, such as organochloride compounds can be controlled from $\mathrm{NaCl}$ concentration added to the real effluent.

Finally, our results (treatment of petrochemical and textile wastewaters) have allowed to start the implementation of a pilot industrial-electrochemical cell in the industry, but these experiments are in progress. Also, it is important to remark that, as the nature of electrode material is an important feature in the electrochemical approaches, the use of a dual arrangement of flow cells for electrochemical decontamination, could be considered as a new alternative [27].

\section{References}

1. Global Economics Paper No: 153 Goldman Sachs. Retrieved on 2013-10-24.

2. Elliott, L. The Guardian, 2011.

3. Ahmaduna, F.-R.; Pendashteh, A.; Chuah Abdullah, L.; Awang Biak, D. R.; Siavash Madaeni, S.; Zainal Abidin, Z. J. Haz. Mat. 2009, 170, 530-551.

4. Coelho, A.; Castro, A.V.; Dezotti, M.; Sant'Anna Jr., G.L. J. Haz. Mat. 2006, 137, 178-184.

5. Diya'uddeen, B.H.; Daud, W.M.A.W.; Abdul Aziz, A.R. Process Saf. Environ. Protect. 2011, 89, 95-105.

6. Doggett, T.; Rascoe, A., Global Energy Demand Seen up 44 Percent by 2030 . http://www.reuters.com/articles/GCAGreenBusiness/idUSN2719528620090527. (Accessed 17.09.13).

7. Marcilly, C. J. Catal., 2003, 216, 47-62.

8. Veil, J.; Puder, M.G.; Elcock, D.; Redweik, R.J.J. Prepared for: U.S. Depart. E. N. E. Tech. Laboratory U. Contract W-31-109Eng-38, 2004.

9. Ekins, P.; Vanner, R.; Firebrace, J. J. Clean. Prod. 2007, 15, 13021315.

10. Fillo, J.P.; Koraido, S.M.; Evans, J.M. Prod. Water: Environmental S. Res. 1992, 46, 151-161.

11. Hansen, B.R.; Davies, S.H. Chem. Eng. Res. Des. 1994, 72, 176188.

12. Rajkumar, D.; Palanivelu, K. J. Haz. Mat. 2004, 113 (1-3), $123-$ 129.

13. Santos, M.R.G.; Goulart, M.O.F.; Tonholo, J.; Zanta, C.L.P.S. Chemosphere 2006, 64, 393-399.

14. Lima, R.M.G.; Silva Wildhagen, G.R.; Cunha, J.W.S.D.; Afonso, J.C. J. Haz. Mat. 2009, 161 (2-3) 1560-1564.

15. Ramalho, A. M.Z.; Martínez-Huitle, C. A.; Silva, D.R., Fuel 2010, 89, 531-534.

16. Rocha, J. H. B.; Gomes, M.S.S.; Fernandes, N.S.; Silva, D.R.; Martínez-Huitle, C.A. Fuel Process. Technol. 2012, 96, 80-87.

17. Santos, D.; Dezotti, M.; Dutra, A.J.B. Chem. Eng. J. 2013, 226, 293-299.

18. Santos, E. V.; Sena, S. F.M.; Silva, D.R.; Ferro, S.; De Battisti, A.; Martínez-Huitle, C. A. Environ. Sci. Pollut. Res. accepted for publication. 2014.

19. Silva, A.J.C.; Santos, E.V.; Morais, C.C.O.; Martínez-Huitle, C.A.; Castro, S.S.L. Chem. Eng. J. 2013, 233, 47-55.

20. Martínez-Huitle, C.A.; Brillas, E.; Appl. Catal. B, 2009, 87, 105.

21. Forgacs, E.; Cserhati, T.; Oros G. Environ. International 2004, 30, 953- 971. 
22. Robinson, T.; McMullan G.; Marchant R.; Nigam P. Bioresour. Technol. 2001, 77, 247-255.

23. Desphande, S.D. Ind. J. Fibre Text. Res., 2001, 26, 136-142.

24. Nava J.L.; Quiroz M.A.; Martínez-Huitle C.A. J. Mex. Chem. Soc. 2008, 52, 249-255.

25. Panizza M.; Oturan M.A. Electrochim. Acta 2011, 56, 70847087.

26. Panizza, M.; Cerisola, G. Appl. Catal. B: Environ. 2007, 75, 95101.

27. Ferreira M.B.; Rocha J.H.B.; Melo J.V.; Martínez-Huitle C.A.; Alfaro M.A.Q. Electrocatalysis 2013, 4, 274-282.

28. Solano, A.M.S.; Rocha J.H. B.; Silva D.R.; Martínez-Huitle C.A.; Zhou M. Oxid. Commun. 2012, 35, 751-758.

29. Solano, A.M.S.; Araújo, C.K.C.; Melo, J.V.; Peralta-Hernandez, J.M.; Silva, D.R.; Martínez-Huitle, C.A. (2013) Appl. Catal. B: Environ. 2013, 130-131, 112-120.

30. Martínez-Huitle, C.A.; Santos, E.V.; Araújo, D.M.; Panizza, M. J. Electroanal. Chem. 2012, 674, 103-107.
31. Solano, A.M.S.; Brito, C.N.; Silva D.R.; Martínez-Huitle, C.A. ECS Trans., 2012, 43, 143-150.

32. Martínez-Huitle, C.A.; Ferro, S. Chem. Soc. Rev. 2006, 35, $1324-$ 1340.

33. Comninellis, Ch.; Chen, G. (eds.). Electrochemistry for the Environment, Springer, 2010.

34. Panizza, M.; Cerisola, G. Chem. Rev. 2009, 109, 6541-6569.

35. Martínez-Huitle, C.A.; Brillas, E. Angew. Chem. Int. Ed. 2008, 47, 1998-2005.

36. Brillas, E.; Sirés, I.; Oturan, M.A. Chem. Rev. 2009, 109, 65706631.

37. Rocha, J. H. B.; Solano, A. M. S.; Fernandes, N. S.; Silva, D. R.; Peralta-Hernández, J. M.; Martínez-Huitle, C. A. Electrocatalysis 2012, 1, 1-12.

38. Bonfatti, F.; Ferro, S.; Lavezzo, F.; Malacarne, M.; Lodi, G.; De Battisti, A. J. Electrochem. Soc. 2000, 147, 592-596.

39. Polcaro, A.M.; Vacca, A.; Mascia, M.; Palmas, S.; Ruiz, J. R. J. Appl. Electrochem. 2009, 39, 2083-2092. 